\title{
Nubsella zeaxanthinifaciens gen. nov., sp. nov., a zeaxanthin-producing bacterium of the family Sphingobacteriaceae isolated from freshwater
}

Correspondence

Dalal Asker

dasker10@gmail.com
Dalal Asker, ${ }^{1,2}$ Teruhiko Beppu ${ }^{2}$ and Kenji Ueda ${ }^{2}$

\author{
${ }^{1}$ Department of Food Science, University of Massachusetts, 100 Holdsworth Way, Amherst, \\ MA 01003, USA \\ ${ }^{2}$ Life Science Research Center, College of Bioresource Sciences, Nihon University, 1866 Kameino, \\ Fujisawa 252-8510, Japan
}

A yellow-pigmented, Gram-negative, strictly aerobic, rod-shaped bacterium (TDMA $-5^{\top}$ ) was isolated from a freshwater sample collected at Misasa (Tottori, Japan). The DNA G+C content was $38.6 \mathrm{~mol} \%$. Major fatty acids were iso $-\mathrm{C}_{15: 0}$, iso- $\mathrm{C}_{17: 0} 3-\mathrm{OH}$ and summed feature 4 (iso- $\mathrm{C}_{15: 0} 2-\mathrm{OH}$ and/or $\mathrm{C}_{16: 1} \omega 7 \mathrm{c}$ ). MK-7 was the predominant respiratory quinone. Zeaxanthin was the major carotenoid pigment produced; flexirubin-type pigments were not produced. TDMA $-5^{\top}$ was sensitive to gamma-irradiation. The strain degraded gelatin, casein, starch, Tween 80 and DNA. Phylogenetic analysis based on the $16 \mathrm{~S}$ rRNA gene sequence placed TDMA $-5^{\top}$ in a distinct lineage in the family Sphingobacteriaceae, sharing 89.4-93.4\% sequence similarity with members of the nearest genus Pedobacter. Strain TDMA $-5^{\top}$ could be distinguished from the other members of the family Sphingobacteriaceae by a number of chemotaxonomic and phenotypic characteristics. Based on its unique phenotypic, genotypic and phylogenetic features, strain TDMA $-5^{\top}$ represents a novel genus and species, for which the name Nubsella zeaxanthinifaciens gen. nov., sp. nov. is proposed. The type strain of Nubsella zeaxanthinifaciens

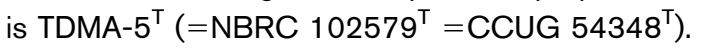

The family Sphingobacteriaceae belongs to the phylum Bacteroidetes and was first proposed by Steyn et al. (1998) to accommodate the genera Sphingobacterium and Pedobacter. Two additional genera, Olivibacter and Parapedobacter, have been proposed recently (Ntougias et al., 2007; Kim et al., 2007). The genus Sphingobacterium, the type genus of the family, was originally described by Yabuuchi et al. (1983) and at present comprises Sphingobacterium antarcticum, S. faecium, S. multivorum, S. spiritivorum, $S$. thalpophilum, S. mizutaii and $S$. daejeonense (Kim et al., 2006; Shivaji et al., 1992; Steyn et al., 1998; Takeuchi \& Yokota, 1992; Yabuuchi et al., 1983). Steyn et al. (1998) proposed the genus Pedobacter initially to accommodate the four heparinolytic species Pedobacter africanus, Pedobacter heparinus, Pedobacter piscium and Pedobacter saltans; nine further species, Pedobacter caeni, Pedobacter cryoconitis, Pedobacter himalayensis, Pedobacter sandarakinus, Pedobacter aquatilis, Pedobacter ginsengisoli, Pedobacter suwonensis, Pedobacter

The GenBank/EMBL/DDBJ accession number for the 16S rRNA gene sequence of Nubsella zeaxanthinifaciens TDMA $-5^{\top}$ is AB264126.

Maximum-likelihood and parsimony phylogenetic trees based on $16 \mathrm{~S}$ rRNA gene sequences, a scanning electron micrograph of cells of strain TDMA $-5^{\top}$ and a detailed fatty acid profile are available as supplementary material with the online version of this paper. panaciterrae and Pedobacter roseus, have since been added (Gallego et al., 2006; Hwang et al., 2006; Kwon et al., 2007; Margesin et al., 2003; Shivaji et al., 2005; Steyn et al., 1998; Ten et al., 2006; Vanparys et al., 2005; Yoon et al., 2006, 2007).

Zeaxanthin $\left(3,3^{\prime}\right.$-dihydroxy- $\beta$-carotene $)$ is a natural, fatsoluble, yellowish carotenoid that is found in some plants, algae and photosynthetic bacteria (Nelis \& De Leenheer, 1989), where it serves as an accessory light-gathering pigment as well as a protectant against the toxic effects of ultraviolet radiation and oxygen radicals. Zeaxanthin is currently utilized as an ingredient in feed for fish and poultry to enhance the pigmentation of animal flesh and egg yolk. Additionally, this pigment has remarkable potential for use in pharmaceuticals, since it prevents age-related macular degeneration and tumour formation. Micro-organisms that produce zeaxanthin belong to various taxa; they include Synechocystis sp. PCC 6803 (Lagarde et al., 2000), Erwinia herbicola (Hundle et al., 1993), Paracoccus zeaxanthinifaciens (Berry et al., 2003; McDermott et al., 1973) and Sphingobacterium multivorum (Alcantara \& Sanchez, 1999; Rosa-Putra et al., 2001).

Recently, we have isolated several zeaxanthin-producing marine bacteria from seawater samples collected on the Pacific coastline of Japan, and two have been identified as 
representing novel genera and species within the family Flavobacteriaceae (Asker et al., 2007a, b). We have also isolated several carotenoid-producing bacteria from freshwater samples that were collected at Misasa (Tottori, Japan), a region known for its high natural radioactivity (Kametani \& Matsumura, 1983). A comprehensive taxonomic characterization based on $16 \mathrm{~S}$ rRNA gene sequences has revealed a unique diversity of carotenoid producers that exists in this radioactive region (unpublished results), and a red-pigmented bacterium (TDMA-17) has been identified as representing a novel species within the genus Sphingomonas that produces astaxanthin (Asker et al., 2007c). In this article, we report the results of a polyphasic taxonomic study of a unique heterotrophic, aerobic, yellow-pigmented bacterium (strain TDMA- $5^{\mathrm{T}}$ ) also isolated from Misasa, which produces zeaxanthin. On the basis of biochemical and chemical criteria and the results of $16 \mathrm{~S}$ rRNA gene sequence analysis, we propose that this isolate represents a novel genus within the family Sphingobacteriaceae.

Strain TDMA-5 ${ }^{\mathrm{T}}$ was isolated from a water sample collected at Misasa on 1 September 2005 by the conventional dilution-plating method using Luria-Bertani (LB) solid medium $\left[1^{-1}: 10 \mathrm{~g}\right.$ polypeptone (Difco), $5 \mathrm{~g}$ yeast extract (Difco), $5 \mathrm{~g} \mathrm{NaCl}$ and $15 \mathrm{~g}$ agar]. Unless otherwise specified, all characteristics described hereafter are those of cells of TDMA $-5^{\mathrm{T}}$ grown on LB for 3 days at $30{ }^{\circ} \mathrm{C}$. The phylogenetic position of the isolate was studied by standard analysis based on the $16 \mathrm{~S}$ rRNA gene sequence. Genomic DNA of TDMA $-5^{\mathrm{T}}$ was extracted using a bacterial genomic DNA purification kit (Edge BioSystems). A DNA fragment that contained nearly the complete $16 \mathrm{~S}$ rRNA gene of TDMA $-5^{\mathrm{T}}$ (1422 bp) was amplified using the bacterial universal primers B8F (5'-AGAGTTTGATCCTGGCTCAG; positions 8-27 based on Escherichia coli numbering) and B1492R (5'-GGTTACCTTGTTACGACTT; positions 1510-1492). The 16S rRNA gene was sequenced directly by using the BigDye Terminator v3.1 cycle sequencing kit on an ABI 3100 automated DNA sequencer (Applied Biosystems).

A sequence similarity search in the GenBank/EMBL/DDBJ nucleotide sequence databases performed using the BLASTN program (http://www.ncbi.nlm.nih.gov/BLAST/) revealed that strain TDMA $-5^{\mathrm{T}}$ belonged to the family Sphingobacteriaceae.

A neighbour-joining phylogenetic tree was constructed using the CLUSTAL W (Thompson et al., 1994) and NJPlot (Perrière \& Gouy, 1996) programs. The tree topology was estimated by a bootstrap analysis (Felsenstein, 1993) with 1000 resamplings of the dataset. Strain TDMA $-5^{\mathrm{T}}$ formed a clade together with several uncharacterized bacterial strains with sequence similarities of $96-97 \%$. This clade did not cluster robustly with any recognized species or genus (Fig. 1). Strain TDMA- $5^{\mathrm{T}}$ was nearest to the members of the genus Pedobacter (except Pedobacter saltans), with $16 \mathrm{~S}$ rRNA gene sequence similarity ranging from 90.3 to 93.4\%. TDMA- $5^{\mathrm{T}}$ exhibited low $16 \mathrm{~S}$ rRNA gene sequence similarity to the type strain of Pedobacter saltans (89.4\%). Sequence similarities between TDMA $-5^{\mathrm{T}}$ and other relatives ranged from 87.6 to $89.8 \%$; they include Sphingobacterium species (87.6-88.9\%), Olivibacter sitiensis AW- $6^{\mathrm{T}}(89.8 \%)$ and Parapedobacter koreensis Jip $14^{\mathrm{T}}$ $(89.3 \%)$.

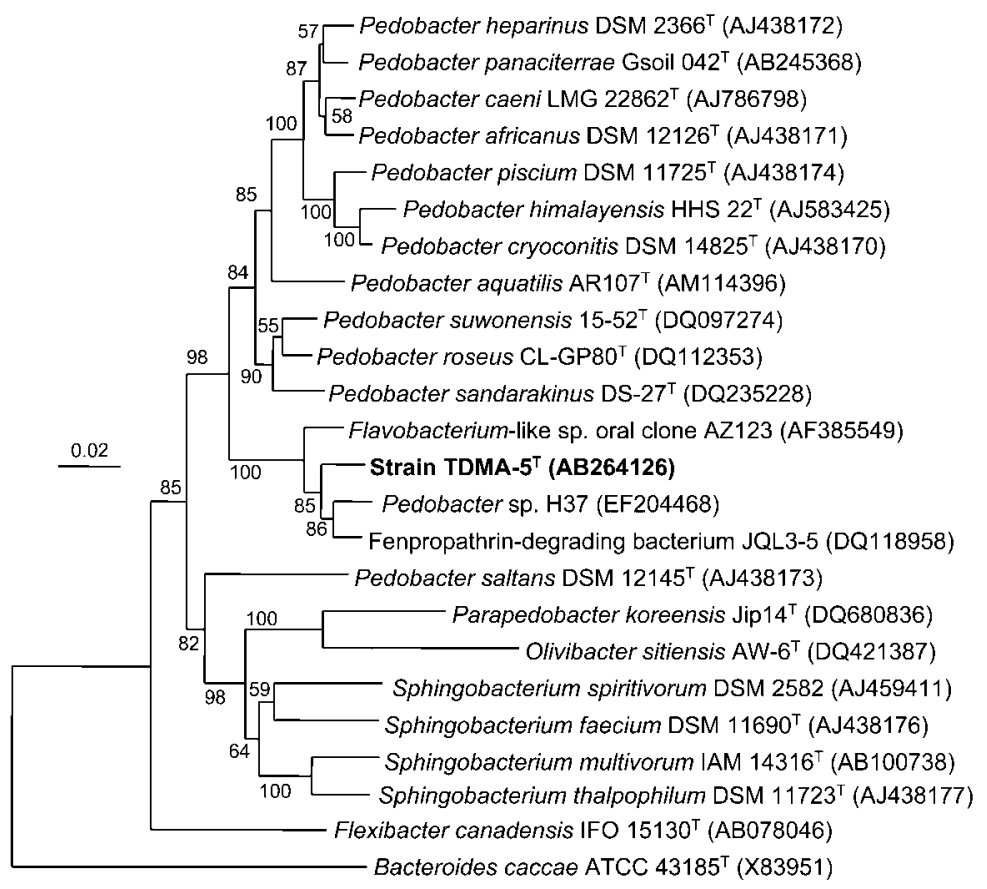

Fig. 1. Phylogenetic tree based on the $16 \mathrm{~S}$ rRNA gene sequences of strain TDMA $-5^{\top}$ and representative members of related genera of the family Sphingobacteriaceae. The tree was constructed by the neighbour-joining method (Saitou \& Nei, 1987). Bar, 2 substitutions per 100 nucleotide positions. Bootstrap values, expressed as percentages of 1000 replicates, are given at branching points; values above $50 \%$ are shown. The $16 \mathrm{~S}$ rRNA gene sequence from Bacteroides caccae ATCC $43185^{\top}$ was used as the outgroup. GenBank accession numbers are shown in parentheses. 
It is evident from the phylogenetic tree (Fig. 1) that strain TDMA $-5^{\mathrm{T}}$ belongs to a distinct lineage in the family Sphingobacteriaceae that is most closely related to Pedobacter species excluding Pedobacter saltans, which clearly formed a monophyletic clade. Pedobacter saltans exhibited low 16S rRNA gene sequence similarity to other Pedobacter species (89.4-91.4\%), and joined the cluster comprising Sphingobacterium species, Olivibacter sitiensis AW $-6^{\mathrm{T}}$ and Parapedobacter koreensis Jip $14^{\mathrm{T}}$ with a low bootstrap resampling value. These results agree with previous phylogenetic studies based on 16S rRNA gene sequences (Kim et al., 2007; Kwon et al., 2007; Ntougias et al., 2007; Shivaji et al., 2005; Ten et al., 2006; Yoon et al., 2006, 2007). Accordingly, P. saltans may have to be reclassified as a member of a new genus. Trees based on maximum-parsimony and maximum likelihood methods showed essentially the same topology (see Supplementary Fig. S1 in IJSEM Online). The results of phylogenetic analysis thus suggest that TDMA $-5^{\mathrm{T}}$ represents a novel genus within the family Sphingobacteriaceae.

The yellow pigments were extracted and analysed using HPLC-MS (LCMS-2010EV; Shimadzu) according to the method described previously (Asker et al., 2007a, b). The menaquinone content was determined by an HPLC method (Collins, 1994). Fatty acid methyl esters of TDMA $-5^{\mathrm{T}}$ were extracted and analysed according to the standard protocol of the Sherlock Microbial Identification System (version 5.0; MIDI). The DNA G + C content was determined by an HPLC method (Mesbah \& Whitman, 1989).

The yellow pigments of strain TDMA $-5^{\mathrm{T}}$ were identified as carotenoids, among which zeaxanthin was predominant [UV-Vis $\lambda_{\max } 451$ and $476 \mathrm{~nm}$; molecular mass $\left(\mathrm{M}^{+}+1\right)$, 569]. Menaquinone-7 (MK-7) was the major respiratory quinone. MK-7 is characteristic of the majority of species within the family Sphingobacteriaceae. The predominant cellular fatty acids were iso- $\mathrm{C}_{15: 0}(29.4 \%)$, iso- $\mathrm{C}_{17: 0} 3-\mathrm{OH}$ $(15.9 \%)$ and summed feature 4 (iso- $\mathrm{C}_{15: 0} 2-\mathrm{OH}$ and/or $\left.\mathrm{C}_{16: 1} \omega 7 c\right)(20.1 \%)$. These fatty acids represented $65.4 \%$ of the total fatty acids of TDMA $-5^{\mathrm{T}}$ (Supplementary Table S1). The major fatty acids of all members of the family Sphingobacteriaceae are iso- $\mathrm{C}_{15: 0}$, iso- $\mathrm{C}_{17: 0} 3-\mathrm{OH}$, iso$\mathrm{C}_{15: 0}$ 2-OH and $\mathrm{C}_{16: 1} \omega 7 \mathrm{c}$ (Kim et al., 2006, 2007; Margesin et al., 2003; Ntougias et al., 2007; Shivaji et al., 2005; Steyn et al., 1998; Vanparys et al., 2005; Yoon et al., 2006). However, TDMA- $5^{T}$ differed from Pedobacter species, Sphingobacterium species, Olivibacter sitiensis $\mathrm{AW}-6^{\mathrm{T}}$ and Parapedobacter koreensis $\mathrm{Jip} 14^{\mathrm{T}}$ by the presence of various minor fatty acid components including $\mathrm{C}_{17: 0}$, $\mathrm{C}_{15: 0} 3-\mathrm{OH}$ (except for Parapedobacter koreensis Jip14 ${ }^{\mathrm{T}}$ ), $\mathrm{C}_{17: 0} 3-\mathrm{OH}$, iso- $\mathrm{C}_{13: 0}$, iso- $\mathrm{C}_{14: 0}$ and $\mathrm{C}_{17: 1} \omega 6 c$ (Table 1). Strain TDMA $-5^{\mathrm{T}}$ differed from members of all related genera by the absence of $\mathrm{C}_{16: 1} \omega 5 c$.

The DNA G + C content of TDMA $-5^{\mathrm{T}}$ was $38.6 \mathrm{~mol} \%$ (Table 1), in agreement with values of $36.9-44.2 \mathrm{~mol} \%$ for the family Sphingobacteriaceae (Steyn et al., 1998).
Gram staining was performed according to the method described by Smibert \& Krieg (1994), and bacterial cells were observed under a Zeiss Axioskop 2 microscope. Scanning electron microscope observation was performed using a model VE-8800 (Keyence). Anaerobic growth was assessed on LB agar incubated in a GasPak anaerobic system (BBL). The following tests were performed as described in each cited reference: casein hydrolysis (Norris et al., 1985) and catalase activity, spore formation and hydrolysis of Tween 80, DNA and starch (Smibert \& Krieg, 1994). Oxidase activity was tested by using commercial cytochrome oxidase test strips (BioChemika). Other enzyme activities, growth on carbohydrates, acid production from carbohydrates, nitrate reduction and the production of $\mathrm{H}_{2} \mathrm{~S}$, indole and acetoin were examined using the commercial systems API 20E, API 20NE and API $50 \mathrm{CH}$ (bioMérieux) according to the manufacturer's instructions. To determine the optimal growth temperature, the strain was cultivated on LB agar at 4, 10, 20, 30, 37,40 and $45{ }^{\circ} \mathrm{C}$. To determine the survival rate after exposure to gamma radiation, cells of TDMA $-5^{\mathrm{T}}$ were grown on an LB plate and suspended in LB broth $(5 \mathrm{ml})$. Aliquots of the cell suspension $(1 \mathrm{ml})$ were irradiated at $2.35 \mathrm{kGy}$ (13 Gy $\min ^{-1},{ }^{137} \mathrm{Cs}$ source), diluted serially and plated onto LB agar. The plates were incubated aerobically at $30{ }^{\circ}$ C. E. coli C600 was similarly treated. Percentage survival was determined by comparison with unirradiated cultures.

Cells of strain TDMA $-5^{\mathrm{T}}$ were Gram-negative rods $(0.2-$ $0.3 \times 1.0-5.0 \mu \mathrm{m})$. A scanning electron micrograph is available as Supplementary Fig. S2. Spores were not observed. Strain TDMA $-5^{\mathrm{T}}$ formed deep yellow-pigmented, circular, convex, shiny, opaque and slimy colonies (2$3 \mathrm{~mm}$ in diameter) that are slightly adherent to agar, with entire margins after 3 days of incubation at $30^{\circ} \mathrm{C}$ on $\mathrm{LB}$ agar plates. The temperature range for growth of TDMA $-5^{\mathrm{T}}$ was $18-40{ }^{\circ} \mathrm{C}$ (optimum, $30{ }^{\circ} \mathrm{C}$ ). No growth occurred at $45{ }^{\circ} \mathrm{C}$. The $\mathrm{pH}$ range for growth was $\mathrm{pH}$ 6.0-9.0. Strain TDMA $-5^{\mathrm{T}}$ was strictly aerobic and chemo-organotrophic. The strain exhibited positive reactions for oxidase and catalase. TDMA $-5^{\mathrm{T}}$ was sensitive to gamma-irradiation. Other phenotypic properties of strain TDMA $-5^{\mathrm{T}}$ are given in the species description and those characteristics that differentiate strain TDMA $-5^{\mathrm{T}}$ from related members of the family Sphingobacteriaceae are listed in Table 1.

Strain TDMA $-5^{\mathrm{T}}$ differed from the members of Pedobacter by having different minor fatty acids, being more mesophilic, being less psychrotolerant (no data were available for Pedobacter caeni, Pedobacter africanus or Pedobacter saltans) and being able to assimilate malate. TDMA $-5^{\mathrm{T}}$ differed from the members of Sphingobacterium by having different minor fatty acids, being less psychrotolerant, being able to assimilate malate, being unable to ferment glucose and being unable to hydrolyse urea. TDMA $-5^{\mathrm{T}}$ differed from Olivibacter sitiensis AW $-6^{\mathrm{T}}$ by having different minor fatty acids, having a narrower temperature growth range, being able to assimilate malate 
Table 1. Differentiation of Nubsella zeaxanthinifaciens gen. nov., sp. nov. TDMA $-5^{\top}$ from related genera of the family Sphingobacteriaceae

Taxa: 1, strain TDMA-5 ${ }^{\mathrm{T}}$; 2, Pedobacter (13 species) (data from Gallego et al., 2006; Hwang et al., 2006; Kwon et al., 2007; Margesin et al., 2003; Shivaji et al., 2005; Steyn et al., 1998; Ten et al., 2006; Vanparys et al., 2005; Yoon et al., 2006, 2007); 3, Sphingobacterium (7 species) (Kim et al., 2006; Shivaji et al., 1992; Steyn et al., 1998; Takeuchi \& Yokota, 1992); 4, Olivibacter sitiensis AW-6 ${ }^{\mathrm{T}}$ (Ntougias et al., 2007); 5, Parapedobacter koreensis Jip $14^{\mathrm{T}}$ (Kim et al., 2007). In all studies, cells for fatty acid methyl ester analysis were grown in peptone-yeast extract media at $28-30{ }^{\circ} \mathrm{C}$. + , Positive; -, negative; $v$, variable; tr, trace; ND, no data available.

\begin{tabular}{|c|c|c|c|c|c|}
\hline Characteristic & 1 & 2 & 3 & 4 & 5 \\
\hline \multicolumn{6}{|l|}{ Growth at: } \\
\hline $5{ }^{\circ} \mathrm{C}$ & - & $+^{*}$ & $\mathrm{~V}$ & + & - \\
\hline $40{ }^{\circ} \mathrm{C}$ & + & - & $\mathrm{V}$ & + & + \\
\hline $42{ }^{\circ} \mathrm{C}$ & - & - & $\mathrm{V}$ & + & + \\
\hline Glucose fermentation & - & $\mathrm{V}$ & + & ND & + \\
\hline Nitrate reduction & - & - & $\mathrm{V}$ & $\mathrm{ND}$ & - \\
\hline Arginine dihydrolase & - & $\mathrm{V}^{*}$ & ND & ND & - \\
\hline Lipase & + & $\mathrm{V}$ & $\mathrm{V}$ & $-\dagger$ & - \\
\hline \multicolumn{6}{|l|}{ Hydrolysis of: } \\
\hline DNA & + & $\mathrm{v}$ & $\mathrm{v}$ & ND & ND \\
\hline Gelatin & + & $\mathrm{v}$ & $\mathrm{V}$ & $\mathrm{ND}$ & - \\
\hline Starch & + & $\mathrm{v}$ & $\mathrm{V}$ & - & ND \\
\hline Aesculin & + & $\mathrm{v}$ & $\mathrm{V}$ & ND & + \\
\hline Urea & - & - & $\mathrm{V}$ & ND & - \\
\hline \multicolumn{6}{|l|}{ Assimilation of: } \\
\hline Glucose & + & $\mathrm{v}$ & + & + & + \\
\hline Arabinose & - & $\mathrm{v}$ & $\mathrm{V}$ & $\mathrm{ND}$ & - \\
\hline Mannitol & - & $\mathrm{v}$ & $\mathrm{V}$ & - & + \\
\hline Maltose & + & $\mathrm{V}$ & + & - & + \\
\hline Malate & + & - & - & - & - \\
\hline$N$-Acetyl-D-glucosamine & + & + & $\mathrm{ND}$ & $\mathrm{ND}$ & + \\
\hline \multicolumn{6}{|l|}{ Minor fatty acids $(\%)$ : } \\
\hline $\mathrm{C}_{17: 0}$ & $+(0.1)$ & - & - & - & - \\
\hline $\mathrm{C}_{15: 0} 3-\mathrm{OH}$ & $+(1.3)$ & - & - & - & $+(1.7)$ \\
\hline $\mathrm{C}_{17: 0} 3-\mathrm{OH}$ & $+(0.6)$ & - & - & - & - \\
\hline iso- $\mathrm{C}_{13: 0}$ & $+(0.6)$ & - & - & - & - \\
\hline iso- $\mathrm{C}_{14: 0}$ & $+(0.3)$ & - & - & - & - \\
\hline $\mathrm{C}_{16: 1} \omega 5 c$ & - & $\mathrm{V}(\operatorname{tr}-3.0)$ & $\mathrm{V}(\operatorname{tr}-1.5)$ & $+(1.3)$ & - \\
\hline $\mathrm{C}_{17: 1} \omega 6 c$ & $+(0.8)$ & - & - & - & - \\
\hline DNA G $+C$ content $(\mathrm{mol} \%)$ & 38.6 & $36.9-44.2$ & $37.7-44.2$ & 45.6 & 45.6 \\
\hline
\end{tabular}

*No data available for Pedobacter caeni, Pedobacter africanus or Pedobacter saltans.

$\dagger$ Tween 20 is not hydrolysed.

and maltose, being able to hydrolyse starch and having a lower DNA G + C content. Finally, TDMA $-5^{\mathrm{T}}$ differed from Parapedobacter koreensis Jip $14^{\mathrm{T}}$ by having different minor fatty acids, being able to assimilate malate and not able to assimilate mannitol, being able to hydrolyse gelatin, being unable to ferment glucose and having a lower DNA $\mathrm{G}+\mathrm{C}$ content.

Based on the result of 16S rRNA gene-based phylogenetic analysis and on the above-mentioned phenotypic features, we conclude that TDMA $-5^{\mathrm{T}}$ represents a novel genus and species within the family Sphingobacteriaceae, for which we propose the name Nubsella zeaxanthinifaciens gen. nov., sp. nov.

\section{Description of Nubsella gen. nov.}

Nubsella (Nub.sel'la. N.L. fem. dim. n. Nubsella arbitrary name derived from the acronym NUBS for Nihon University College of Bioresource Sciences, where the type species was first isolated).

Gram-negative, non-spore-forming rods. Strictly aerobic. Catalase- and oxidase-positive. MK-7 is the only respiratory quinone. Carotenoid pigments are produced. As determined by $16 \mathrm{~S}$ rRNA gene sequence analysis, the genus Nubsella is a member of the family Sphingobacteriaceae. The $\mathrm{G}+\mathrm{C}$ content of the type strain of the type species is $38.6 \mathrm{~mol} \%$. The type species of the genus is Nubsella zeaxanthinifaciens. 


\section{Description of Nubsella zeaxanthinifaciens sp. nov.}

Nubsella zeaxanthinifaciens (ze.a.xan.thi.ni.fa'ci.ens. N.L. neut. n. zeaxanthinum zeaxanthin; L. part. pres. faciens making/producing; N.L. part. adj. zeaxanthinifaciens zeaxanthin-producing).

Displays the following characteristics in addition to those given in the genus description. Cells are motile, 0.2$0.3 \times 1.0-5.0 \mu \mathrm{m}$. Forms deep-yellow, circular, convex, shiny, opaque and slimy colonies that are slightly adherent to agar, with entire margins and a diameter of $2-3 \mathrm{~mm}$ on LB agar plates after 3 days incubation at $30{ }^{\circ} \mathrm{C}$. Contains non-diffusible yellow carotenoid pigments, with zeaxanthin as the major component. Growth occurs between 18.0 and $40.0{ }^{\circ} \mathrm{C}$ (optimum, $30.0{ }^{\circ} \mathrm{C}$ ) and between $\mathrm{pH} 6.0$ and 9.0 (optimum, $\mathrm{pH}$ 6.0-7.0). Anaerobic growth does not occur. Tween 80, starch, gelatin, casein, aesculin and DNA are hydrolysed, while agar is not. Indole and $\mathrm{H}_{2} \mathrm{~S}$ are not produced. Nitrate is not reduced. Glucose, mannose, $\mathrm{N}$-acetylglucosamine, maltose and malate are assimilated, but arabinose, mannitol, gluconate, capric acid, adipic acid, trisodium citrate and phenylacetic acid are not. In API $20 \mathrm{E}$ tests, $\beta$-galactosidase and the Voges-Proskauer test are positive; tests for arginine dihydrolase, lysine decarboxylase, ornithine decarboxylase, tryptophan deaminase, hydrogen sulphide and indole production and urease are negative. Acid is not produced from D-glucose, melibiose, amygdalin, L-arabinose, D-mannitol, inositol, D-sorbitol, L-rhamnose or sucrose. Major fatty acids are iso- $\mathrm{C}_{15: 0}$, iso- $\mathrm{C}_{17: 0} 3-\mathrm{OH}$ and summed feature 4 (iso- $\mathrm{C}_{15: 0} 2-\mathrm{OH}$ and/or $\mathrm{C}_{16: 1} \omega 7 c$ ).

The type strain is TDMA $-5^{\mathrm{T}}\left(=\mathrm{NBRC} 102579^{\mathrm{T}}=\mathrm{CCUG}\right.$ $54348^{\mathrm{T}}$ ), isolated from a freshwater sample collected at Misasa (Tottori, Japan).

\section{Acknowledgements}

We thank Dr Tarek S. Awad for critical reading of the manuscript. We also thank Akira Seto for sample collection, Hoshio Eguchi for his assistance with gamma-irradiation and Shoichi Amano for his assistance with electron microscope observations. This research was supported by the 21st century COE program of the Ministry of Education, Culture, Sports, Science and Technology, Japan. D. A. was supported by a fellowship from the Japan Society for the Promotion of Science.

\section{References}

Alcantara, S. \& Sanchez, S. (1999). Influence of carbon and nitrogen sources on Flavobacterium growth and zeaxanthin biosynthesis. J Ind Microbiol Biotechnol 23, 697-700.

Asker, D., Beppu, T. \& Ueda, K. (2007a). Mesoflavibacter zeaxanthinifaciens gen. nov., sp. nov., a novel zeaxanthin-producing marine bacterium of the family Flavobacteriaceae. Syst Appl Microbiol 30, 291-296.

Asker, D., Beppu, T. \& Ueda, K. (2007b). Zeaxanthinibacter enoshimensis gen. nov., sp. nov., a novel zeaxanthin-producing marine bacterium of the family Flavobacteriaceae, isolated from seawater off Enoshima Island, Japan. Int J Syst Evol Microbiol 57, 837-843.

Asker, D., Beppu, T. \& Ueda, K. (2007c). Sphingomonas astaxanthinifaciens sp. nov., a novel astaxanthin-producing bacterium of the family Sphingomonadaceae isolated from Misasa, Tottori, Japan. FEMS Microbiol Lett 273, 140-148.

Berry, A., Janssens, D., Humbelin, M., Jore, J. P., Hoste, B., Cleenwerck, I., Vancanneyt, M., Bretzel, W., Mayer, A. F. \& other authors (2003). Paracoccus zeaxanthinifaciens sp. nov., a zeaxanthinproducing bacterium. Int J Syst Evol Microbiol 53, 231-238.

Collins, M. D. (1994). Isoprenoid quinones. In Chemical Methods in Prokaryotic Systematics, pp. 265-310. Edited by M. Goodfellow \& A. G. O'Donnell. Chichester: Wiley.

Felsenstein, J. (1993). PHYLIP (phylogeny inference package), version 3.5. Distributed by the author. Department of Genome Sciences, University of Washington, Seattle, USA.

Gallego, V., Garcia, M. T. \& Ventosa, A. (2006). Pedobacter aquatilis sp. nov., isolated from drinking water, and emended description of the genus Pedobacter. Int J Syst Evol Microbiol 56, 1853-1858.

Hundle, B. S., O'Brien, D. A., Beyer, P., Kleinig, H. \& Hearst, J. E. (1993). In vitro expression and activity of lycopene cyclase and betacarotene hydroxylase from Erwinia herbicola. FEBS Lett 315, 329-334.

Hwang, C. Y., Choi, D. H. \& Cho, B. C. (2006). Pedobacter roseus sp. nov., isolated from a hypertrophic pond, and emended description of the genus Pedobacter. Int J Syst Evol Microbiol 56, 1831-1836.

Kametani, K. \& Matsumura, T. (1983). Determination of ${ }^{238} \mathrm{U},{ }^{234} \mathrm{U}$, ${ }^{226} \mathrm{Ra}$ and ${ }^{228} \mathrm{Ra}$ in spring waters of Sanin district. Radioisotopes 32, 18-21 (in Japanese).

Kim, K. H., Ten, L. N., Liu, Q. M., Im, W. T. \& Lee, S. T. (2006). Sphingobacterium daejeonense sp. nov., isolated from a compost sample. Int J Syst Evol Microbiol 56, 2031-2036.

Kim, M. K., Na, J. R., Cho, D. H., Soung, N. K. \& Yang, D. C. (2007). Parapedobacter koreensis gen. nov., sp. nov. Int J Syst Evol Microbiol 57, 1336-1341.

Kwon, S. W., Kim, B. Y., Lee, K. H., Jang, K. Y., Seok, S. J., Kwon, J. S., Kim, W. G. \& Weon, H. Y. (2007). Pedobacter suwonensis sp. nov., isolated from the rhizosphere of Chinese cabbage (Brassica campestris). Int J Syst Evol Microbiol 57, 480-484.

Lagarde, D., Beuf, L. \& Vermaas, W. (2000). Increased production of zeaxanthin and other pigments by application of genetic engineering techniques to Synechocystis sp. strain PCC 6803. Appl Environ Microbiol 66, 64-72.

Margesin, R., Spröer, C., Schumann, P. \& Schinner, F. (2003). Pedobacter cryoconitis sp. nov., a facultative psychrophile from alpine glacier cryoconite. Int J Syst Evol Microbiol 53, 1291-1296.

McDermott, J. C., Britton, G. \& Goodwin, T. W. (1973). Carotenoid biosynthesis in a Flavobacterium sp.: stereochemistry of hydrogen elimination in the desaturation of phytoene to lycopene, rubixanthin and zeaxanthin. Biochem J 134, 1115-1117.

Mesbah, M. \& Whitman, W. B. (1989). Measurement of deoxyguanosine/thymidine ratios in complex mixtures by high-performance liquid chromatography for determination of the mole percentage guanine + cytosine of DNA. J Chromatogr 479, 297-306.

Nelis, H. J. \& De Leenheer, A. P. (1989). Profiling and quantitation of bacterial carotenoids by liquid chromatography and photodiode array detection. Appl Environ Microbiol 55, 3065-3071.

Norris, J. R., Ribbons, D. W. \& Varma, A. K. (editors) (1985). Methods in Microbiology, vol. 18. London: Academic Press.

Ntougias, S., Fasseas, C. \& Zervakis, G. I. (2007). Olivibacter sitiensis gen. nov., sp. nov., isolated from alkaline olive-oil mill wastes in the region of Sitia, Crete. Int J Syst Evol Microbiol 57, 398-404. 
Perrière, G. \& Gouy, M. (1996). WWW-query: an on-line retrieval system for biological sequence banks. Biochimie 78, 364-369.

Rosa-Putra, S., Hemmerlin, A., Epperson, J., Bach, T. J., Guerra, L. H. \& Rohmer, M. (2001). Zeaxanthin and menaquinone-7 biosynthesis in Sphingobacterium multivorum via the methylerythritol phosphate pathway. FEMS Microbiol Lett 204, 347-353.

Saitou, N. \& Nei, M. (1987). The neighbor-joining method: a new method for reconstructing phylogenetic trees. Mol Biol Evol 4, 406-425.

Shivaji, S., Ray, M. K., Rao, N. S., Saisree, L., Jagannadham, M. V., Kumar, G. S., Reddy, G. S. N. \& Bhargava, P. M. (1992). Sphingobacterium antarcticus sp. nov., a psychrotrophic bacterium from the soils of Schirmacher Oasis, Antarctica. Int J Syst Bacteriol 42, 102-106.

Shivaji, S., Chaturvedi, P., Reddy, G. S. \& Suresh, K. (2005). Pedobacter himalayensis sp. nov., from the Hamta glacier located in the Himalayan mountain ranges of India. Int J Syst Evol Microbiol 55, 1083-1088.

Smibert, R. M. \& Krieg, N. R. (1994). Phenotypic characterization, In Methods for General and Molecular Bacteriology, pp. 607-654. Edited by P. Gerhardt, R. G. E. Murray, W. A. Wood \& N. R. Krieg. Washington, DC: American Society for Microbiology.

Steyn, P. L., Segers, P., Vancanneyt, M., Sandra, P., Kersters, K. \& Joubert, J. J. (1998). Classification of heparinolytic bacteria into a new genus, Pedobacter, comprising four species: Pedobacter heparinus comb. nov., Pedobacter piscium comb. nov., Pedobacter africanus sp. nov. and Pedobacter saltans sp. nov. Proposal of the family Sphingobacteriaceae fam. nov. Int J Syst Bacteriol 48, $165-177$.
Takeuchi, M. \& Yokota, A. (1992). Proposals of Sphingobacterium faecium sp. nov., Sphingobacterium piscium sp. nov., Sphingobacterium heparinum comb. nov., Sphingobacterium thalpophilum comb. nov. and two genospecies of the genus Sphingobacterium, and synonymy of Flavobacterium yabuuchiae and Sphingobacterium spiritivorum. J Gen Appl Microbiol 38, 465-482.

Ten, L. N., Liu, Q.-M., Im, W.-T., Lee, M., Yang, D.-C. \& Lee, S.-T. (2006). Pedobacter ginsengisoli sp. nov., a DNase-producing bacterium isolated from soil of a ginseng field in South Korea. Int J Syst Evol Microbiol 56, 2565-2570.

Thompson, J. D., Higgins, D. G. \& Gibson, T. J. (1994). CLUSTAL W: improving the sensitivity of progressive multiple sequence alignment through sequence weighting, position-specific gap penalties and weight matrix choice. Nucleic Acids Res 22, 4673-4680.

Vanparys, B., Heylen, K., Lebbe, L. \& De Vos, P. (2005). Pedobacter caeni sp. nov., a novel species isolated from a nitrifying inoculum. Int J Syst Evol Microbiol 55, 1315-1318.

Yabuuchi, E., Kaneko, T., Yano, I., Moss, C. W. \& Miyoshi, N. (1983). Sphingobacterium gen. nov., Sphingobacterium spiritivorum comb. nov., Sphingobacterium multivorum comb. nov., Sphingobacterium mizutae sp. nov., and Flavobacterium indologenes sp. nov.: glucosenonfermenting gram-negative rods in CDC groups IIK-2 and IIb. Int $J$ Syst Bacteriol 33, 580-598.

Yoon, J.-H., Lee, M.-H., Kang, S.-J., Park, S.-Y. \& Oh, T.-K. (2006). Pedobacter sandarakinus sp. nov., isolated from soil. Int J Syst Evol Microbiol 56, 1273-1277.

Yoon, M.-H., Ten, L. N., Im, W.-T. \& Lee, S.-T. (2007). Pedobacter panaciterrae sp. nov., isolated from soil in South Korea. Int J Syst Evol Microbiol 57, 381-386. 